
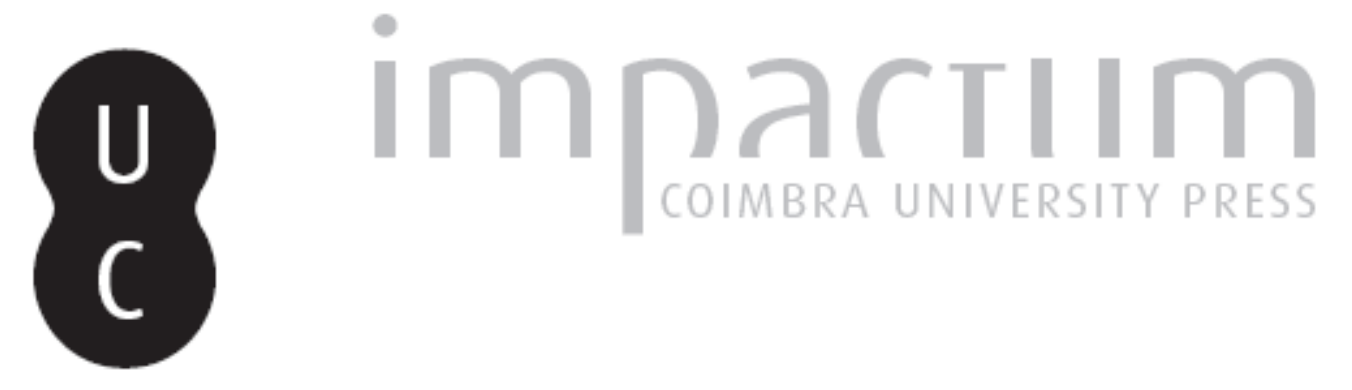

\title{
Stone Raft: allegory on the spread of European urbanistics in Early Modern times
}

\author{
Autor(es): Rossa, Walter
}

Publicado por: Editorial do Departamento de Arquitetura

URL persistente:

URI:http://hdl.handle.net/10316.2/39941

DOI:

DOI:https://doi.org/10.14195/1647-8681_6_7

Accessed : $\quad$ 26-Apr-2023 09:08:57

A navegação consulta e descarregamento dos títulos inseridos nas Bibliotecas Digitais UC Digitalis, UC Pombalina e UC Impactum, pressupõem a aceitação plena e sem reservas dos Termos e Condições de Uso destas Bibliotecas Digitais, disponíveis em https://digitalis.uc.pt/pt-pt/termos.

Conforme exposto nos referidos Termos e Condições de Uso, o descarregamento de títulos de acesso restrito requer uma licença válida de autorização devendo o utilizador aceder ao(s) documento(s) a partir de um endereço de IP da instituição detentora da supramencionada licença.

Ao utilizador é apenas permitido o descarregamento para uso pessoal, pelo que o emprego do(s) título(s) descarregado(s) para outro fim, designadamente comercial, carece de autorização do respetivo autor ou editor da obra.

Na medida em que todas as obras da UC Digitalis se encontram protegidas pelo Código do Direito de Autor e Direitos Conexos e demais legislação aplicável, toda a cópia, parcial ou total, deste documento, nos casos em que é legalmente admitida, deverá conter ou fazer-se acompanhar por este aviso. 


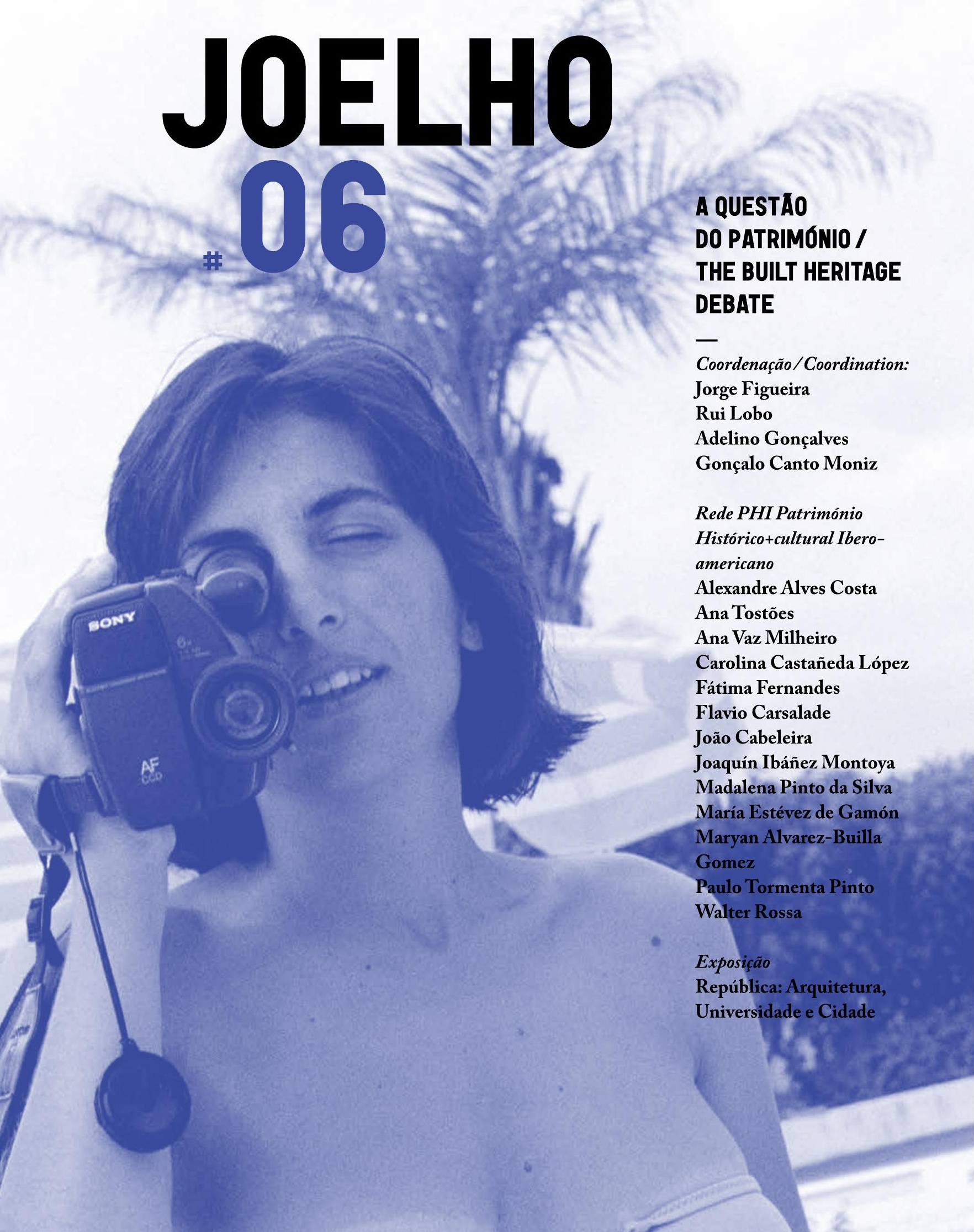




\section{Walter Rossa ${ }^{\text {ess, sase, ve, erenseat }}$}

Stone Raf́t: all legory on the spread of European urbanistics in Early Modern times

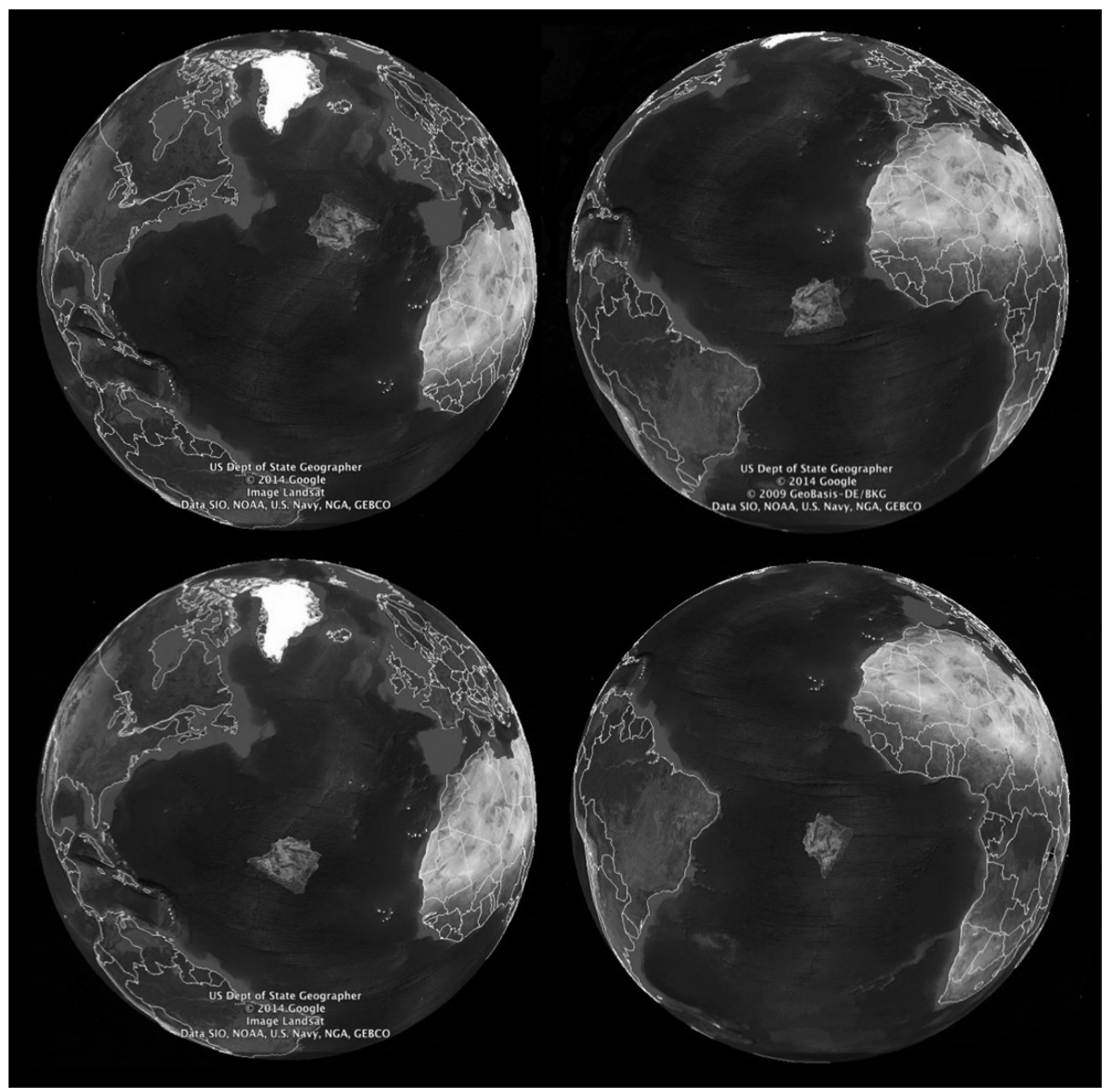


1.

The Stone Raft is the title of a novel published in 1986 by the Nobel prizewinner José Saramago, which has been enormously successful, having been published in over two dozen languages (Saramago, 1986). The complex plot develops around an unusual motif: the Iberian Peninsula breaks off from the European landmass, and floats off into the Atlantic in the direction of the Azores. This "raft" lingers for some time in mid ocean, as if hesitating between the United States and Europe, and suddenly starts to spin. It rotates for a month before being projected southwards. At this point, it is noticed that all the women on the peninsula are pregnant. Finally, it comes to a halt somewhere between South America and Africa. Then, Iberia becomes a small continent, or large island, in the middle of the South Atlantic (fig. 1). Behind, now open to the North Atlantic, stays the Mediterranean.

The Stone Raft is essentially a fantastic allegory, a biting and sometimes satirical critique of many aspects of the age, particularly the end of Three Worlds Theory and the concomitant reorganisation of the Western hegemonic blocs. It is no coincidence that the book appeared the year Portugal and Spain joined the European Economic Community. The author was one of the most strident voices protesting against Portugal's integration into Europe, gradually coming out in favour of Iberian federalization. He believed that the Iberian countries were being side-lined by European unification, and that they were adrift, unable to identify with the rest of the continent culturally, socially or economically.

However, I am not going to defend or even discuss these controversial aspects of Saramago's book. I merely wish to make use of the allegory about Iberia being transported away from Europe, and getting stuck in the sea between the continents it helped to shape. Admittedly this was not always through the most laudable processes, but for good and for worse its consequences are today's reality. From slave trafficking to Catholic proselytizing, from the reconnoitring, description and design of its territories, peoples, wildlife, plants, etc. to the implementation of urban networks: this was a process of expansion, in which western civilization was reshaped, using as tools language, faith and urbanization. It is the last of these that I shall be considering here. This is a story that is often overlooked outside Portuguese and Spanish languages cultural universes, and so I shall begin by sketching it out.

2.

As well as a long shared border that is nowhere justified by geographic variation, Spain and Portugal have many more things in common than they have divergences. For their present configurations, more important than neighbourly conflict is the story of their reciprocal influences and complementarity. For this reason, they have been much compared, which accentuates their differences and causes us to forget how (when seen together in the global context) they constitute a unit, though one that is strengthened by a rich diversity. Throughout history, this unit
1. The stone raft Iberia in its Saramago's travel from Europe till the South Atlantic. 




anvabalate ole troino

(i)

iitilitiliti

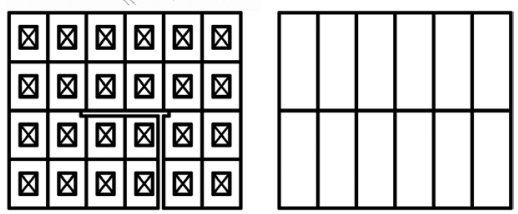

2. Synthesis on the original plot systems from Mediterranean and central Europe (Trindade, 2009: 39-81). Composition made with material from: top left, an almoada house in Silves (Portugal) by Rosa Varela Gomes (1998), "O Barlavento algarvio nos finais da islamização." Portugal Islâmico: os últimos sinais do Mediterrâneo. Lisboa: Museu Nacional de Arqueologia: 139-140; top right, detail with Troino's neighbourhood riverside from a drawing of Setubal and river Sado's mouth, Biblioteca Nacional da Ajuda (Lisbon); boton, Jiménes Castillo \& Navarro Palazón (2001: 113). encountered and processed all kinds of cultural influences from the Mediterranean and Atlantic, from North and South, evolving from a peripheral backwater into the raft that connected Europe with the rest of the world. It is in the interests of all that this role should be intensified.

Before the two countries became sovereign states with territories similar in shape to what they are today, they underwent a very similar historical process, particularly as regards the cadence and significance of the various invasions (Roman, Germanic, Islamic) that brought the cultural influences that differentiated it since the beginning from the rest of Europe. The definition of these sovereignties was induced by a final invasion by the knights of non-Mediterranean Europe, in the guise of a crusade against Islamic domination, who joined the HispanoRoman Christians taking refuge in the Asturias, in what is generally known as the Christian Reconquest. That was also fostered by the pilgrimage to Saint James shrine.

Along with various other innovations, this last wave (which took place between the $11^{\text {th }}$ and $12^{\text {th }}$ centuries) brought the knights mentioned in the previous paragraph (who produced an important renovation in the landholding and courtly nobility), the Gregorian Reform and its religious orders, and a considerable number of Central European merchants and traders descended upon Iberia in order to become closer to the flourishing Islamic trade. These groups brought new habits and innovations in the religious, military, commercial and administrative spheres, reintroducing Roman law and also new rural and urban territorial planning models. The settlement and resettlement of remote conquered territories occurred at the same time as the ethnic and religious groups in the cities and country were being switched and replaced.

This vast operation of Iberian reurbanization involved the systematic obliteration of the urban and allotment structures of the Islamicized cities; others were then built on top of them in accordance with the paradigms of medieval European town planning, then being consolidated (Gutiérrez Lloret, 1993; Pinon, 2001; Jiménes Castillo \& Navarro Palazón, 2001; Torró Abad, 1993; Trindade, 2007). In these cases, it was naturally not easy to achieve the geometric-morphological refinement evident in the many new towns that were sprouting up at that time (fig. 2). Iberia was, like other regions of Europe, an excellent ground for trying out territorial planning and town creation processes, and it was at that time that its urban network acquired the structure that can still be seen today, and, with it, all the types of urban spaces familiar to European cities (Betran Abadia, 1992; Sopena \& Urteaga, 2006; Trindade, 2009).

However, elements of Mediterranean spatial culture (Greeks, Romans, Muslims) persisted, blending together or transmuting, and traces of them are still perceptible in the terminology, even more in architecture and construction than in urbanism. In fact, despite the ostensible denial of Mediterranean-Islamic matrices in that urbanistic restructuring, there was nevertheless recognition of the aesthetic worth, seclusion and comfort 


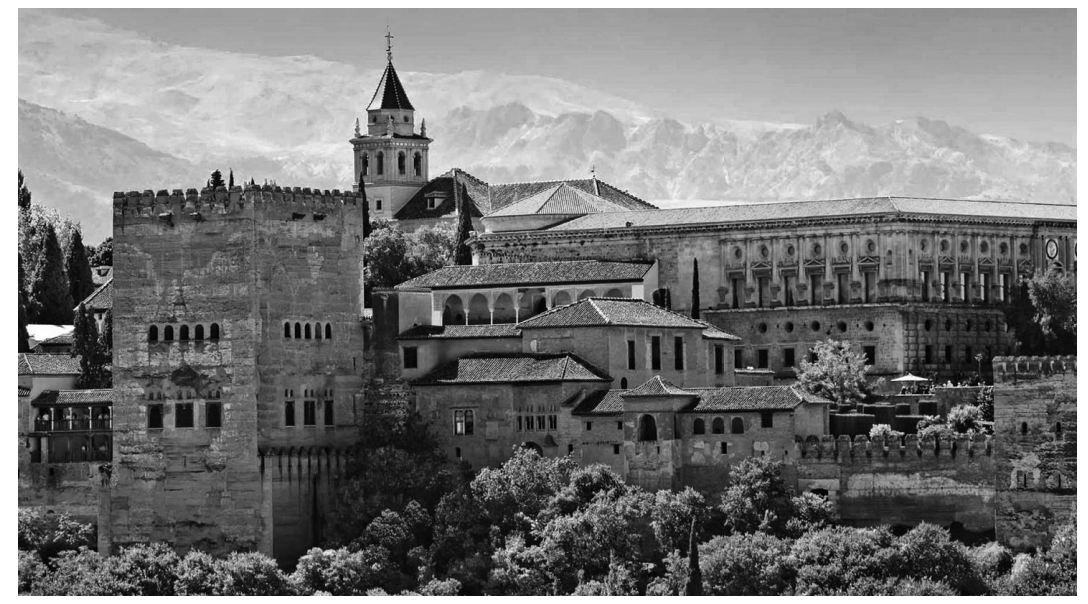

offered by its palatial architecture. While it was generally considered important to establish the European Christian form of urban street sociability, and urban spaces that were adjacent and continuous the elites gradually became aware of the elegance of domestic life since Antiquity around the Mediterranean. Thus, Renaissance architecture flourished in the Iberian Peninsula alongside the Muslim and Mudejar (fig. 3).

This intense coexistence of oppositions and compositions occurred in a vaster context in which the Iberian expansion to North Africa arose as the "natural" continuation of the Christian Reconquest, corroborated by a series of papal bulls designed to incite and regulate it. The expansion took a long time, due to the persistence of the Islamic kingdom of Granada until 1492. By 1415 Portugal had advanced onto Ceuta. Just as Portuguese nationality was only consolidated in the middle of the $13^{\text {th }}$ century, when sovereignty was extended to the whole of what is Portugal's present-day territory, the unification of its neighbour under the idea of the Kingdom of Spain, only became possible after the conquest of Granada by the Catholic Monarchs. That is to say, the composition of each of the Iberian states depended on the success of the Reconquest.

The fact that, by the end of the $15^{\text {th }}$ century, the Iberian kingdoms had the means to expel Muslim domination from the Peninsula and proceed overseas, is related to their efforts to exploit the sea route in order to find partners for contracts that would help them overcome their peripheral status in relation to the large centres and axes of European trade, which to a large extent were supplied by the caravans that came from Africa and Asia to the Mediterranean. In the year of the conquest of Granada, the armada of Cristóvão Colombo reached the Antilles. Four years before, Bartolomeu Dias had discovered the Cape route. In 1479, the Iberian sovereigns had made a first agreement about how to divide up the world they were discovering, and then, after acquiring a clearer idea of what that entailed, celebrated another in 1494 (the Treaty of Tordesillas) with completely opposing rules (fig. 4). Not for another four centuries, in Berlin, did Europeans dare to divide up the world between them once again. 
4. The lines defined by the treaties of Tordesillas (1494) and Zaragoza (1529) over a map with the World's main regions of Portuguese cultural influence.

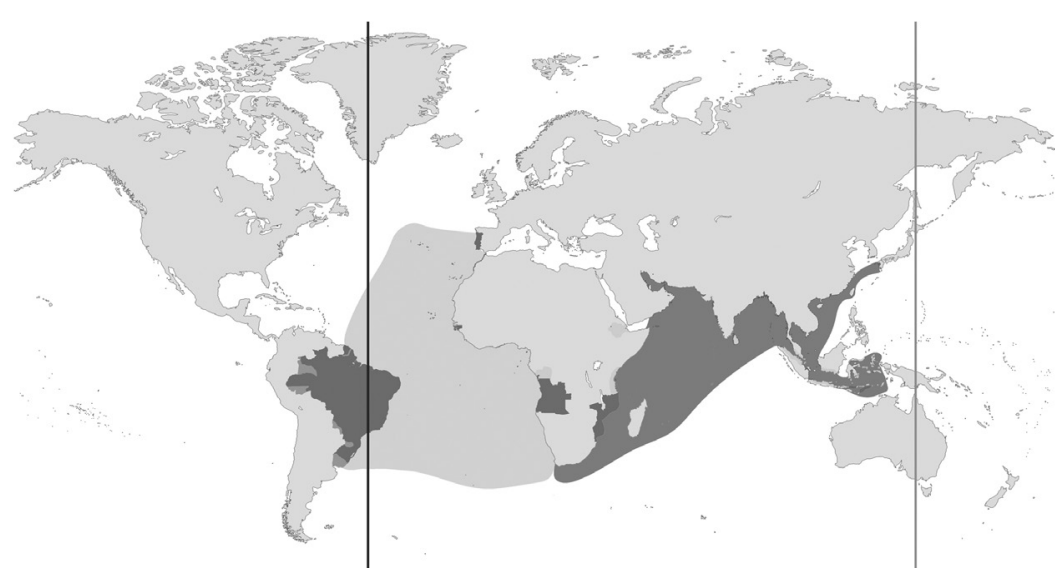

This division of the world gave the two Iberian countries very diverse territories, which naturally required very different processes of appropriation. This was exacerbated by the fact that Spain had much a larger population than Portugal and thus much greater emigration potential. In the first decades of its overseas expansion, Spain invested heavily in territorial conquest in the Americas (with Cortés conquering the Mexico of the Aztecs around 1520, Pizarro the Peru of the Incas in 1532, etc.). Portugal, on the other hand, sought compromise solutions along the coasts of Africa and Asia, which allowed it to gain dominion of the seas and thus of trade with minimal territorial bases. The occupation that later became Brazil was delayed and protracted, despite the fact that the indigenous communities offered little resistance. In fact, Portuguese territorial actions in India, Africa and Brazil, were much more triggered by local reactions or the appearance of third parties, than by previously defined plans or intentions.

In this brief description of the main characteristics of the territorial processes involved in the overseas expansion of the Iberian kingdoms in the Early Modern Age, we should not forget that, in the Portuguese case, it involved individuals of different ranks and nationalities. In fact, much of the Portuguese presence in Asia was actually secured by freelancers who had served the Crown directly for some time, and thereby earned the right to set up on their own, exploiting the places, routes and trading opportunities that they wished. Ultimately, all commerce had to pass through Goa what assured the Crown the fiscal required returns. These adventurers often collaborated with the missionaries from the Portuguese Padroado, who were themselves of many different nationalities. In a letter written in Malacca on 20 July 1549, while preparing his trip to Japan with two other Jesuits, also Spanish, St Francisco Xavier declared: "we are going three Portuguese."

The main points of friction between the Iberian empires were the lines that delimited the territories they claimed as their own in Iberia, America and Asia. From the Middle Ages until the independence of the American territories, the state of play was marked by a succession of treaties. However, from La Plata basin to Macau and Manila, these 
borderlands were not so much battlefields as spaces of cultural and mercantile interchange, which developed to a wealthy contraband; that is to say, there was a kind of functional promiscuity between the two empires.

Both languages were used in the Portuguese and Spanish courts of the $15^{\text {th }}$ and $16^{\text {th }}$ centuries, and in the theatre and publishing, despite the fact that they were beginning to be formally differentiated and codified. There were several projects for dynastic union, such as the one involving the prince Miguel da Paz, recognized as heir to both crowns, though this was invalidated by his early death in 1500 . Navigators, cartographers and other professionals involved in the expansion, served both sovereigns almost indifferently, concerned only to get support for their proposals. For example, in 1493, Colombo, returning from his first trip to the Antilles, landed in Lisbon to confer with the Portuguese king before heading to Seville to consult the Catholic Monarchs; similarly, Fernão de Magalhães, who was Portuguese and always had served the Portuguese Crown, approached Charles V about the proposed expedition to the Moluccas, which ultimately led to the first circumnavigation of the globe and to the Spanish settlement at Filipinas.

To sum up, before moving onto questions directly related with urbanization, the allegory of the stone raft allows us to sense how the unprecedented exploration, interpretation and conceptualization of the globe was being carried out from Iberia, in this early $16^{\text {th }}$ century. An Iberia moored to Europe by the Pyrenees and culturally nourished by everything that was arriving through them. In this task, the Spanish and Portuguese acted like close enemies, warring and spying with each other, but joining up whenever third parties threatened their maritime hegemony that was naturally doomed to disappear. When that time came, at the turn of the $16^{\text {th }} / 17^{\text {th }}$ centuries, the empires of Portugal and Spain were reunited under the Habsburg Crown, though the most important aspects of their functional and power systems were not integrated, thus making possible a return to separation in 1640.

3.

Historiographies of Spanish and Portuguese urbanization and urbanism began to appear more or less at the same time in the 1950s (Smith, 1954; Garcia Bellido et al, 1954; Chicó, 1956; Silveira, 1956). However, the larger morphological variety and complexity of the Portuguese cases (compared with the Spanish checker or, better, damero) meant that they were prematurely and naively interpreted and labelled as organic, spontaneous or even as resulting from a lack of interest in order and organization.

Although studies published in the next decade demonstrated quite the reverse (França, 1962; Reis, 1964; Santos, 1968), the slow pace and limited volume of this output, meant that this perception only began to alter in Portuguese-speaking academic environments from the 1980s (Araujo \& Carita, 1982-1997; Correia, 1984; Terán, 1989; Ciudad Iberoamericana..., 


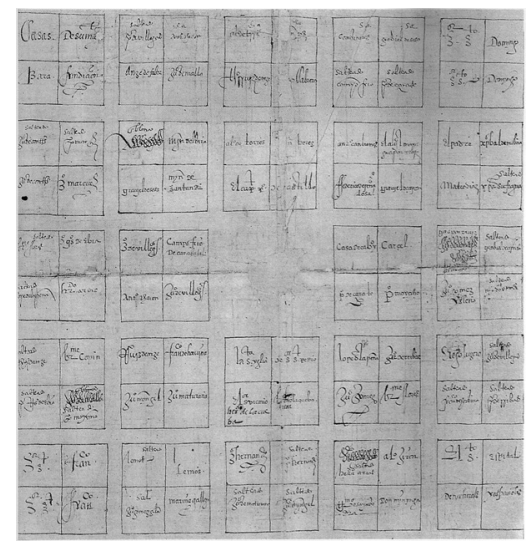

5. Foundational plan for the city of Mendoza (Argentina), 1562. Archivo General de Indias (Sevilla).
1985; Ferrão, 1985; Fernandes, 1987; Gutiérrez, 1992; Rossa, 1995a; Estudios..., 1999; Rossa et al, 1999; Teixeira \& Valla, 1999). Misconceptions still remain today, particularly abroad, despite the efforts of some authors to publish in other languages (Delson, 1979; Rossa, 1990; Rossa, 1994; Rossa, 1995b; Rossa \& Trindade, 2006; Tostões \& Rossa, 2008; Mattoso, 2010; Rossa, 2010a). On the Spanish side, despite its ample divulgation, it seems to prevail, not only an over simplified perception of the damero, as well as a general unawareness of the most up to date bibliography. In fact, nothing is ever so linear as the great syntheses produced by comparative studies in global history, particularly when ill-informed.

The reduction of Spanish colonial urbanism to the archetypal damero straight out of the Leys de Indias of 1573 is a good example of this. As has already been amply demonstrated by many colleagues in different works (Terán, 1989; Gutiérrez, 1992), there were many Spanish cities founded in the Americas that did not follow that model, and around 250 cases appeared before that norm was established (Paula, 1999). Thus, the model was integrated into the prior Spanish urbanistic culture, and though it was a first general option, it was not universal. As often happens, the norm enshrined existing practice, rather than imposing an innovation. The damero is in essence the urbanistic model that had most critical success since Antiquity, continued and transmitted in the most diverse forms, particularly through military encampments and presidiums. It has been shown how the orthogonal grid model was present in Iberian culture throughout the Middle Ages (including in some of the first known urbanistic theoretical proposals), and how it was not a Spanish creation (Betran Abadia, 1992; Sopena \& Urteaga, 2006; Trindade, 2009).

Spanish was, however, the way it was systematized in the new contexts of America, particularly for the formation of plots on territories where there was almost infinite space, which clashed with habits acquired in cramped European cities. Also Spanish was the way it was connected to a southern style of architecture adapted to hotter climates, using the traditional Mediterranean model of the courtyard houses for generous plots, close to the square proportion, and crowned with terraced roofs. Also pragmatically Spanish was the way in which the city squares, contravening legislation, were formed by the simple removal of a block, rather than from the removal of a quarter of four adjoining blocks, so that two main roads axis crossed in the middle of it (fig. 5). I could continue with this characterization, though it is not necessary for this lecture purposes. What I really want to stress here is: a) how the famous Hispanic-American damero is a large-scale evolution and adaptation of what was the commonest model for colonization newtowns since at least Hellenistic times; b) how this induces a particular form of sociability, as social life and organization are inseparable from urban form, particularly from the plot.

Let us now relate the adoption of this model to what I mentioned above about how the different conditions in the territories, claimed by each of the two Iberian crowns, dictated processes of acting that were 
necessarily diverse. The orthogonal grid model of town planning, with the square block as its base module, is explained in part by the military and demographic conditions sustaining the Spanish case. What was the Portuguese model like and how can it be explained? Did there exist a model, as in the Spanish case, or a rule?

With the exception of the islands that still integrate Portugal nowadays, it was in the Indian Ocean that the Portuguese structured their first cities outside Europe. They resulted from gradual processes of two types: either the adaptation of pre-existing urban structures, or the establishment of a trading post, which was then converted into a fortification, which in turn gave rise to an urban centre, etc. The first cases almost always resulted from processes of conquest, the second from agreements with local sovereign. With few settlers, the dimension, density and pace of the process were always rather limited (Rossa, 1995b; Rossa, 2010b). Conclusion: as they never had the ideal minimum conditions for a general conception and planned implementation of the towns, it is not possible to gauge whether or not there was an archetype.

However, important political changes such as the adoption of a strategy for the creation of a state with some territorial support in the 1530s, seams to lead to a different practice: Bassein and Daman urban morphologies clearly exhibit prior planning (fig. 6). Also, in some sectors of the rapidly growing capital Goa, there are indications that new urban expansions were being planned. The neighbourhood of Tranqueira in Malacca (fig. 7), built from a pre-existing road, is a clearer example, because the urban structure is still visible today. In all the others, the obliteration of any evidence of the allotment, and the fact that it is not represented with any rigour in the graphic material of the period, make it impossible to carry out geometric-algebraic morphological studies like those that have revealed the structuring of towns in other parts of the Portuguese universe. Other cases in the East, such as Macau or Meliapor, resulted from processes launched by merchants and in which the action of the Crown was felt much later, and only very tenuously (Mattoso, 2010: vol. Asia and Oceania).

Yet, the greatest destination for the exportation of European urbanistic culture by the Portuguese was Brazil, which began to manifest itself in the second half of the $16^{\text {th }}$ century, gaining pace a century later. Till then the Portuguese concentrated upon controlling trade in the Indian Ocean, and so were less interested in explore and develop the Brazilian coastline. The first attempt came in the 1530s with the threat of occupation by the French, and the appearance of the first serious difficulties in the East. It consisted of granting colonization rights and obligations to private parties, which, from a global perspective, did nothing. A decade later the Crown reacted decreeing that a general government should be created for Brazil and a capital founded to serve it as a base: Salvador da Bahia. The process, launched in 1548, involved despatching a master-stonemason equipped with models and designs to be adapted to the local context (Simas Filho, 1979).

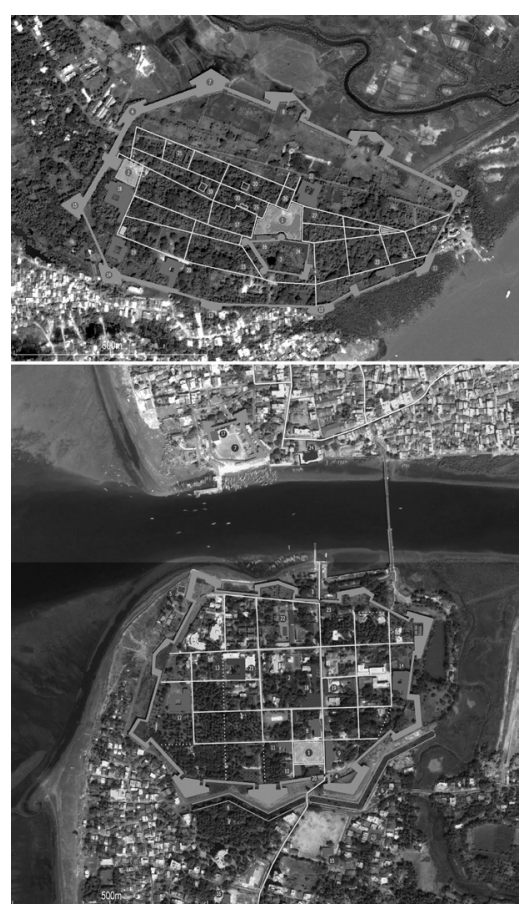

6. Plan of the cities of Bassein and Daman (India) over satellite photos (Mattoso, 2010: vol. Asia and Oceania: 159 and 101).

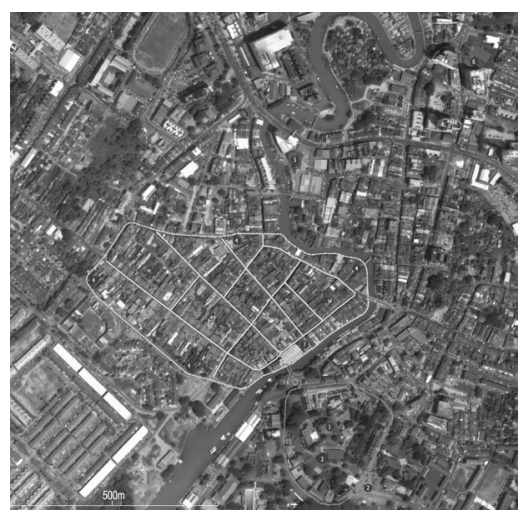

7. Plan of the city of Malacca (Malaysia) over satellite photo (Mattoso, 2010: vol. Asia and Oceania: 449). 
Salvador was thus the first city founded as such by the Portuguese in South America. It was conceived as a very small fortified structure established on a site that was chosen for its natural defensive characteristics. The shape was determined by the small platform revealed after the land had been cleared and quickly expanded to the next platform, linked by the construction of a cathedral (fig. 8). The layout, despite constraints, is carefully executed, tending towards a grid and structured around a square for the civil power and another for the religious. The plots are very hybrid, which does not allow us to draw any major conclusions, or perhaps points to hesitations in the way the urban property was to be allotted.

The first governor of Brazil was charged with the ordering of the previous settlements, but in fact there was little to do. It was the settlement of a group of Huguenots in the Bay of Guanabara in 1555 that prompted significant action, first their expulsion and, ten years later, the founding of Rio de Janeiro (Abreu, 2010). This began on a mound overlooking the bay but soon extended to the floodplains along the waterfront (fig. 9). It was structured in a very similar way to other Portuguese cities in Europe and the Atlantic islands, such as the represented on the image (fig. 10). It is not possible to describe them all, however what is important is that they all originated either from cities consolidated during the Middle Ages (in case of mainland Portugal) or from early sites of occupation (in the case of the islands), which were subsequently extended. This leads us to the question of the archetype.

Despite their morphological diversity, all these cases have something in common: they are structured from a module that is the plot and not the block. Long narrow plots, with the house in the front and usually a yard behind, forming longish blocks that hierarchize the streets grid (fig. 11). Plots with slight deformations of the rectangular base are able to adapt very well to the morphological and topographical constraints of the terrain, which means that each case acquires its own peculiar form (Rossa, 2013: 124-131). This meant that, in addition to flexibility (which a model does not have), it also induces a different kind of sociability. This affects the internal composition of the houses (which were necessarily more open to the exterior than a courtyard house), and results in a different kind of architectural organization and expression. Thus, in order to interpret the relationship between form and society, it is necessary to study the family cell, that is, the individual house and the plot.

Just as the chessboard composition model used and developed by the Spanish in the Americas was not its creation, the rule based on modulated land division into long narrow plots had other antecedents. It entered the Peninsula in the $11^{\text {th }}$ and $12^{\text {th }}$ centuries with the waves of Christians from non-Mediterranean Europe, mentioned earlier. The vast majority of towns founded by the Iberian Christian kingdoms followed this rule. With its simplicity, adaptability and gradualness, this rule better served a process with the characteristics described above for the Portuguese one (Rossa et al, 2001; Rossa, 2010a). However, it is less 

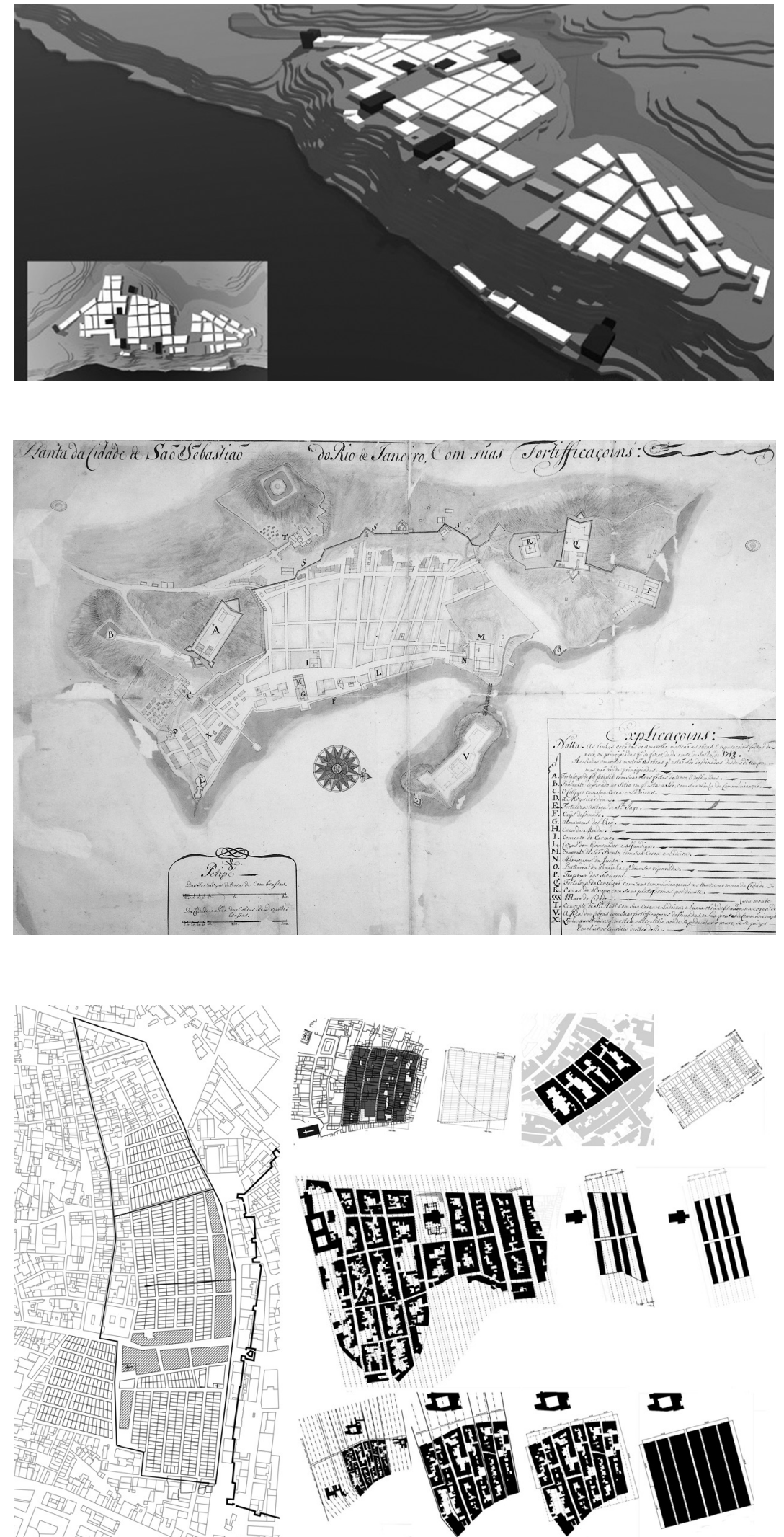

9. João Massé, Planta da Cidade de São Sebastião do Rio de Janeiro..., 1714, Arquivo Histórico Ultramarino (Lisboa).
10. Portuguese urbanism grid and plot system examples from the Middle Age till the $16^{\text {th }}$ century. Left, Bairro Alto (Lisbon), from 1513 till the 1550's (Walter Rossa (2012), "História(s) do património urbanístico." Fomos condenados à cidade: uma década de estudos sobre património urbanístico. Coimbra: Imprensa da Universidade. 2015: 59-80); top, Nisa and Arronches

(Trindade, 2009); middle, Angra, bottom, Ponta Delgada (Antonieta Reis Leite (2012), Açores, cidade e território: quatro vilas estruturantes. Angra do Heroismo: Instituto Açoreano de Cultura. 2015). 


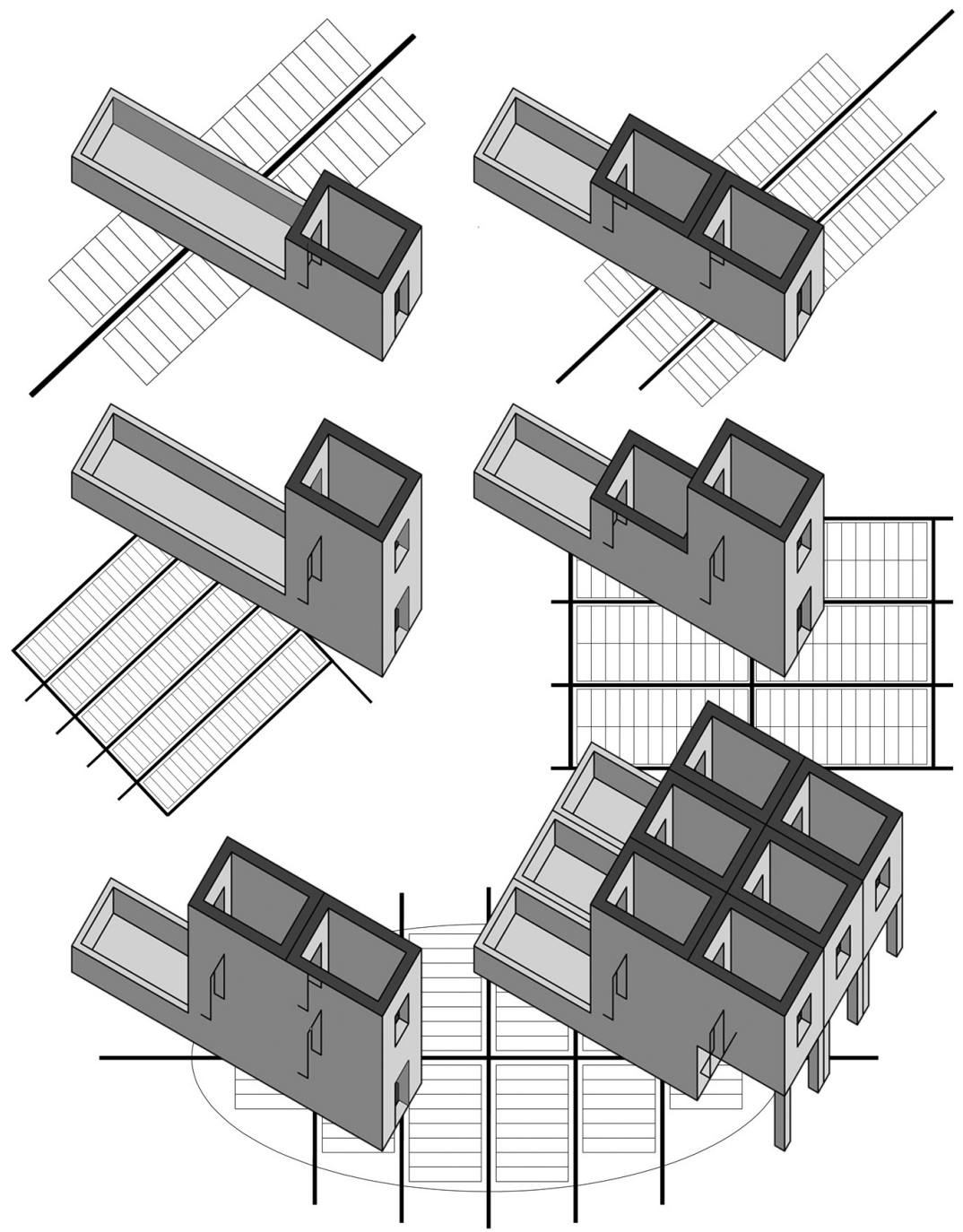

easy to perceive than the damero, which confused the first scholars of Portuguese urbanism in the Americas, generating a misconception that has persisted in historiography.

The cities founded in Brazil followed that rule. The pace was slow during the 60 years of the Iberian Union (1580-1640). In at least one of those cases, founded in 1585 and suggestively entitled Filipeia (today João Pessoa), the damero was initially used. However, the structured grid imposed after the 1615 Portuguese takeover of the S. Luís fort (which had been founded three years earlier by the French in Maranhão) is misleading, as its layout follows the modular rule of the long thin plot. This was the first of many cases in which Portuguese military engineers sought to merge the two systems. There were also attempts at fusion on the Spanish side. Hence, the stone raft - a fertile incubator in Saramago's novel - had also begun to reproduce and develop on Brazil the archetype that had synthesized in Europe in the Middle Ages. 
4.

The navigation, exploration and start of Iberian colonization of the world over the course of the $16^{\text {th }}$ century, ultimately alerted non-Mediterranean Europe to the benefits of global sea trade. The convergence of the Iberian Union with European conflicts about Charles V's empire, allowed rival sovereignties to openly dispute that trade and vital nodes in its networks. In 1596, the first Dutch squadron, headed by Cornelis de Houtman after he have been two years in Lisbon spying, moved into the Indian Ocean. Curiously, this was the same year as John van Linschoten's Itinerario was published in Amsterdam (Linschoten, 1596). This work (a careful report of everything this other Dutch had seen in the East on the voyage he made on Portuguese ships) was soon followed by other reports of journeys made by the Dutch, English and French to the same ports, and also to South America and Antilles, containing maps with routes, data about navigation, commerce and living, and also plans and descriptions of cities and defensive systems.

Nederland, England and (a half-century later) France, launched their overseas projects almost exclusively for the purpose of trade. Of course, this generated a need for fortified bases and in the long term gave rise to the colonies. At first, the Crowns or states were not directly involved; rather, the task was entrusted to companies. Their ships were militarily very effective, which meant they soon imposed their authority to the detriment of the Iberian armadas. Indeed, this power shift had become clear in 1588 when the English, with Dutch help, vanquished the Spanish Armada, which included 1/ 3 of Portuguese ships.

During their first decades these emerging powers had little ambition for territorial control of the colonial type, which spared most of the Iberian empires where efforts were now being intensified to urbanise and develop territorial occupation. Ultimately Iberian colonialism is generally perceived, although not always assumed, as an archaic and experimental precedent of the "classic" one that comes out from Berlin 1885's conference. In fact, European colonization of the Americas in the $17^{\text {th }}$ and $18^{\text {th }}$ centuries was very urbanising in nature and massively Iberian. In the remoter parts, borders were defined and hundreds of cities founded, gradually refining the Europeans urban model and rule developed by the stone raft. By the time the American colonies acquired independence, the Iberian colonies, such as Brazil, already had recognised structured territories, urban networks and state apparatus. In short, these were ready-made countries.

For better or worse, the stone raft directly produced the pillar of urbanization in Latin America: 20 countries with mostly urban populations, which account for around $8 \%$ of the world population. In area, Latin America covers $13 \%$ of the surface of all the continents. As for Brazil, as well as being one of the large emerging powers, it has $1 / 3$ of the population of Latin America and 44\% of its surface. These figures are impressive enough on their own, but we should also consider the other Portuguese-speaking countries in the world, where (with rare but 
significant exceptions, such as Luanda and the Island of Mozambique), the urbanization process only took place in the $2 \mathrm{O}^{\text {th }}$ century; thus, when these countries acquired independence in 1975, those territories were, once more, mature in urbanising terms. With this, the ratios from stone raft urbanization rose by $1 \%$ in each indicator. In those countries, two similar languages are spoken, the $2^{\text {nd }}$ and $4^{\text {th }}$ most used in the world, with a total of almost $800,000,000$ native speakers.

5.

Having arrived at this point, I would like to make a suggestion, something that already involves many researchers, including myself, but which I believe could include many more.

Global historiographies of cities and urbanism, ignores Portugal and almost ignores Spain (Lavedan, 1926; Lavedan, 1941; Mumford, 1961; Benevolo, 1975; Sica, 1976; Morris, 1979; Guidoni \& Marino, 1979; Guidoni, 1981; Delfante, 1997; Hall, 1999; Clark, 2013). This might be understandable from an exclusively European perspective, though it is odd that there are no references to the 1758 plan for the reconstruction of Lisbon (one of the first integrated plans in the history of town planning) (França, 1962; Tostões \& Rossa, 2008), or to Vila Real de Santo António, a utopian factory-city planned and built in the same time frame as the Saline Royale d'Arc-et-Senans (fig. 12). In this, the fusion between the damero and the long narrow plot has been pushed to the mathematical extreme of a fractal, while the social model is a clear forerunner of the industrial society (Correia, 1984; Horta, 2006; Rossa, 2009).

What I would like to leave to the consideration of this forum is whether, from a global perspective and within a European strategy of global reaffirmation, it makes sense that these same historiographies should continue to approach all the work produced from the stone raft - an extraordinary living European legacy to Humanity - in a factually and methodologically wrong way, ignoring specific and advanced research developed in recent decades. In short, what I suggest to the community of researchers gathered by themes on city and urbanism is that there should be greater adhesion to Saramago's allegoric purpose, leaving the Pyrenees behind and moving in the direction of the South Atlantic, and then travelling by land to the coasts of the Indian and Pacific Oceans.

6.

By the way, allow me to finish with the reading of a truncated excerpt from Saramago's novel: Someone in Europe, sad with Iberia departure, wrote on a corner of a wall: "Nous aussi, nous sommes ibérics [...] This inaugural declaration spread rapidly, it appeared on the façades of the large buildings, on pediments, on pavements, in the corridors subways, on bridges and viaducts [...] it jumped frontiers, and having jumped them it became clear that the same words had already appeared in 


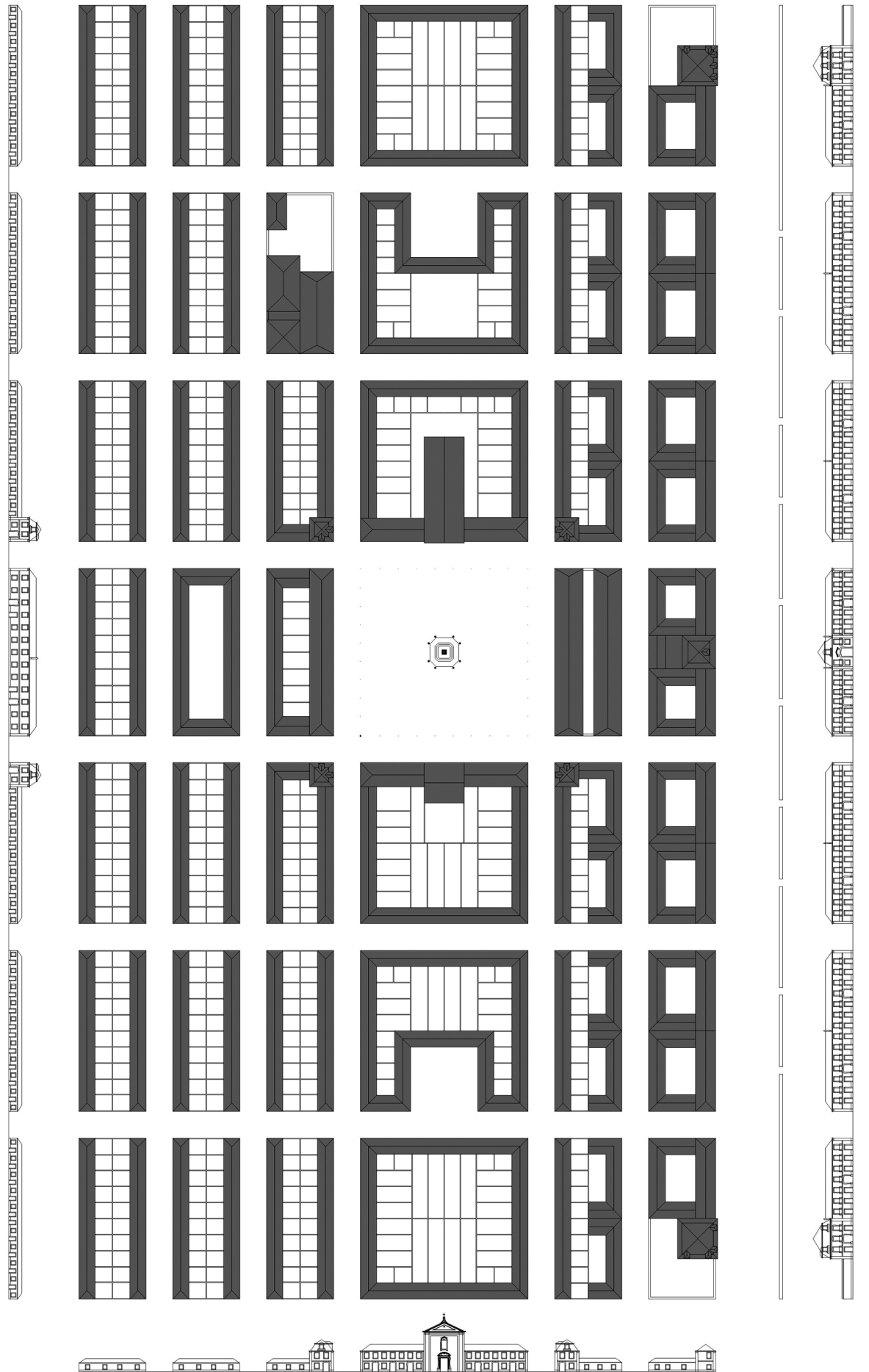

12. Reconstitution of the ideal-foundational plan of Vila Real de Santo António, 1773 [Walter Rossa \& Adelino Gonçalves (coord.). Plano de Pormenor de Salvaguarda do Núcleo Pombalino, 2005]. 
other languages [...]. But the culmination, the climax, the crowning glory, a rare expression we're not likely to repeat, was when on the Vatican walls [...] that same declaration appeared in Latin, Nos quoque iberi sumus [...] From one day to the next, Europe was covered with these slogans. What probably started out as being little more than the futile gesture of an idealist gradually spread until it became an outcry, a protest and public demonstration." (Saramago, 1986: 126-7).

\footnotetext{
The first version of this text was the keynote-plenary lecture made at the opening of the $12^{\text {th }}$ International Conference on Urban History, Cities in Europe Cities in the World, held by the European Association for Urban History at Lisbon,

3 September 2014.
}

\section{Bibliography}

Abreu, Mauricio de A. (2010), Geografia histórica do Rio de Janeiro (1502-1700). Rio de Janeiro: Andrea Jakobsson

Araujo, Renata \& Carita, Helder (org.) (1982-

1997), Colectânea de Estudos: Universo Urbanístico Português 1415-1822. Lisboa: Comissão Nacional para as Comemorações dos Descobrimentos Portugueses. 1998

-

Benevolo, Leonardo (1975), Diseño de la ciudad. Barcelona: Gustavo Gili. 5 vol.s, 1982

-

Betran Abadia, Ramón (1992), La forma de la ciudad. Las ciudades de Aragon en la Edad Media. Zaragoza: Delegación en Zaragoza del Colegio Oficial de Arquitectos de Aragón

Chicó, Mário Tavares (1956), A Cidade Ideal do Renascimento e as cidades portuguesas da Índia. Garcia de Orta, nespecial, 319-328
Ciudad Iberoamericana, La, Actas del Seminario Buenos Aires 1985. Madrid: MOPU - CEHOPU. 1987

Clark, Peter (ed.) (2013), The Oxford Handbook of Cities in World History. Oxford: Oxford University Press

Correia, José Eduardo Horta (1984), Vila Real de Santo António: urbanismo e poder na política pombalina. Porto: FAUP. 1998

-

Delfante, Charles (1997), Grande histoire de la ville: de la Meéopotamieu aux Etáts-Unis. Paris: Colin/Her

Delson, Roberta Marx (1979), New Towns for Colonial Brazil: spacial and social planning of the eighteenth century. Siracuse: Department of Geography of Siracuse University and UMI

-

Estudios sobre el territorio iberoamericano. Sevilla: Junta de Andalucia. 1999
Fernandes, José Manuel (1987), O Lugar da Cidade Portuguesa. Povos e Culturas, 2, 79-112

Ferrão, Bernardo José (1985), Projecto $e$ transformação urbana do Porto na época dos Almadas: 1758/1813. Porto: Faculdade de Arquitectura da Universidade do Porto. 1989

França, José Augusto (1962), Lisboa Pombalina e o iluminismo. Lisboa: Bertrand. 1987

Garcia Bellido, A.; Torres Balbás, L.; Cervera Vera, L.; Chueca Goitia, F.; Bidagor Lasarte, P. (1954), Resumen Historico del Urbanismo en España. Madrid: Instituto de Estudios de Administracion Local. 1987

Guidoni, Enrico (1981), La Città dal medioevo al rinascimento. Bari: Laterza. 1989

Guidoni, Enrico; MARINO, Angela (1979), Storia dell'urbanistica: /l Seicento. Bari: Laterza 
Gutiérrez Lloret, Sónia (1993). De la civitas a la madina: destrucción y formación de la ciudad en el sureste de Al-Andalus. El debate arqueológico. In IV Congreso de Arqueología Medieval Española. Madrid: CSIC. tomol.

Gutiérrez, Ramón (1992), Arquitectura y Urbanismo en Iberoamerica. Madrid: Ediciones Cátedra

Hall, Peter (1998), Cities in Civilization. New York: Fromm International. 2001

Horta, João Manuel Gomes (2006), Vila Real de Santo António, forma limite no Urbanismo Histórico Português. Faro: dissertação de doutoramento apresentada à Faculdade de Ciências Humanas e Sociais da Universidade do Algarve

-

Jiménez Castillo, Pedro \& Navarro Palazón, Julio (2001), El urbanismo islámico y su transformación después de la conquista cristiana: el caso de Murcia. In La ciudad medieval: de la casa al tejido urbano. Cuenca: coord. Jean Passini, Universidad de Castillala-Mancha.

Lavedan, Pierre (1926), Histoire de l'Urbanisme, Antiquité: Moyen Age. Paris: Henri Laurens, Éditeur

Lavedan, Pierre (1941), Histoire de l'Urbanisme: Renaissance et Temps Modernes. Paris: Henri Laurens. 1959

-

Linschoten, John Huyghen van (1596), The voyage of... to the East Indies. New Deli: Asian Educational Services. 2 vol.s, 1988

Mattoso, José (ed.) (2010), Portuguese Heritage Around the World: architecture and urbanism. 3. vol.s. Lisboa: Fundação Calouste Gulbenkian. 2011

Morris, A. E. J. (1979), History of urban form: before the industrial revolutions. Barcelona: Longman

-

Mumford, Lewis (1961), The city in history: its origins, its transformations and its prospects. New York: Harcourt

Paula, Alberto de (1999), Teorías y planes, usos y costumes en la urbanística hispanoamericana. Colóquio Internacional Universo Urbanístico Português 1415-1822. (pp. 117-129). Lisboa: Atas, Comissão Nacional para as Comemorações dos Descobrimentos Portugueses.

-

Pinon, Pierre (2001). La transición desde la ciudad antigua a la ciudad medieval: permanencia y transformación de los tejidos urbanos en el Mediterráneo Oriental. In La ciudad medieval: de la casa al tejido urbano, coord. Jean Passini, Cuenca, Ediciones de la Universidad de Castilla-la-Mancha.

Reis, Nestor Goulart (1964), Contribuição ao Estudo da Evolução Urbana do Brasil (1500/1720). São Paulo: Pini. 2001

-

Rossa, Walter (1990), Beyond Baixa: signs of urban planning in eighteenth century Lisbon. Lisboa: Instituto Português do Património Arquitectónico. 1998
Rossa, Walter (1994), Il terremoto del 1755: una città sotto il segno della ragione. Rassegna. Bologna: Editrice CIPIA, 59, 28-43

Rossa, Walter (1995a), A cidade portuguesa. In História da Arte Portuguesa. Lisboa: Círculo de Leitores. 3 vol.s, vol. III: 233-323 (também publicado em Walter Rossa (2002), A urbe e o traço: uma década de estudos sobre o urbanismo português (192-359). Coimbra: Almedina)

-

Rossa, Walter (1995b), Indo-Portuguese Cities: a contribution to the study of Portuguese urbanism in the Western Hindustan / Cidades Indo-Portuguesas: contribuição para o estudo do urbanismo português no Hindustão Ocidental. Lisboa: Comissão Nacional para as Comemorações dos Descobrimentos Portugueses. 1997

-

Rossa, Walter (2009), Cidades da Razão: Vila Real de Santo António e arredores. Monumentos, 30, 16-31 (também publicado em Walter Rossa (2015), Fomos condenados à cidade: uma década de estudos sobre património urbanístico (pp. 191-217). Coimbra: Imprensa da Universidade.)

-

Rossa, Walter (2010a), Le città nuove dell'universo urbanistico portoghese: invariabilità ed evoluzione. Fondazioni urbane. Città nuove europee dal medioevo al Novecento. Roma: ed. A. Casamento, Edizioni Kappa. 2012: 245-264 (também publicado em Walter Rossa (2002-2013), Fomos condenados à cidade: uma década de estudos sobre património urbanístico. Coimbra: Imprensa da Universidade. 2015: 167-190)

Rossa, Walter (2010b), General Overview: what's what in this book. Portuguese Heritage Around the World: Architecture and urbanism. Ásia e Oceânia (pp. 20-61) Lisboa: Fundação Calouste Gulbenkian, 2011.

-

Rossa, Walter (2013), Património urbanístico: (re) fazer cidade parcela a parcela. Fomos condenados à cidade: uma década de estudos sobre património urbanístico (pp. 97-131). Coimbra: Imprensa da Universidade. 2015

Rossa, Walter; Araujo, Renata; Carita, Helder (org.) (1999), Colóquio Internacional Universo Urbanístico Português 1415-1822. Lisboa: atas, Comissão Nacional para as Comemorações dos Descobrimentos Portugueses. 2001

-

Rossa, Walter; Leite, Antonieta Reis; Coelho, Isadora; Simões, Nuno; Barão, Pedro (2001), Recenseando as invariantes: alinhamento de alguns casos de morfologia urbana portuguesa de padrão geométrico. Actas do V Colóquio Luso-Brasileiro de História da Arte (pp. 61-80). Faro: Universidade do Algarve. 2002: (também publicado em Walter Rossa (2002), A urbe e o traço: uma década de estudos sobre o urbanismo português (pp. 424-443). Coimbra: Almedina)

-

Rossa, Walter \& Trindade, Luísa (2006), Problems and precedents of the «Portuguese City»: understanding medieval urbanism. Murphy, 1, 70-109
Santos, Paulo F. (1968), Formação de cidades no Brasil colonial. Rio de Janeiro: Editora UFRJ. 2001

Saramago, José (1986). The Stone Raft. London: Harvill Press, 2000

-

Sica, Paolo (1976), Storia dell'urbanistica:

II Settecento. Bari: Laterza. 1985

Silveira, Luís (1956), Ensaio de Iconografia das cidades portuguesas do Ultramar. Lisboa: Junta de Investigações do Ultramar. 4 vol.s

-

Simas Filho, Américo (1979), Evolução física de Salvador. Salvador: Fundação Gregório de Mattos. 1998

Smith, Robert C. (1954). Colonial Towns of Spanish and Portuguese America. Journal of the Society of Architectural Historians. Philadelphia: 4 (14), 1955 2-12

-

Sopena, Pascual Martínez \& Urteaga, Mertxe (ed.) (2006), Las villas nuevas medievales del Suroeste europeo. De la fundación medieval al siglo XXI. Análisis histórico y lectura contemporánea, Boletín Arkeolan, 14. Irun: Centro de Estudios e Investigaciones Histórico-Arqueológicas

Teixeira, Manuel C. \& Valla, Margarida (1999), O Urbanismo Português: séculos XIII-XVIII Portugal-Brasil. Lisboa: Livros Horizonte.

Terán, Fernando de (coord.) (1989), La Ciudad Hispanoamericana: el sueño de un orden. Madrid: CEHOPU.

Tostões, Ana \& Rossa, Walter (coord.) (2008), Lisboa 1758: the Baixa plan today, exhibition cathalogue. Lisboa: Câmara Municipal de Lisboa.

Torró Abad, J. (1993), “El urbanismo mudéjar como forma de resistencia. Alquerías y morererías en el reino de Valencia (siglos XIII-XIV)." Actas del Simposio Internacional de Mudejarismo. Zaragoza: Centro de Estudios Mudéjares del Instituto de Estudios Turoleses. 1995

Trindade, Luísa (2007), From Islam to Christianity: urban changes in medieval Portuguese cities. Religion and power in Europe: conflict and convergence (pp. 29-51). Pisa: Pisa University Press.

Trindade, Luísa (2009), Urbanismo na composição de Portugal. Coimbra: Imprensa da Universidade de Coimbra. 2013 